agriTECH, 41 (4) 2021, 344-353

\title{
Karakteristik Fisik, Kimia dan Organoleptik Tiwul Instan Protein Tinggi Bersubtitusi Tepung Koro Pedang (Canavalia ensiformis L.)
}

\author{
Physical, Chemical, and Organoleptic Characteristics of High-Protein Instant Tiwul Subtituted with Jack Bean \\ Flour (Canavalia ensiformis L.)
}

\section{H. Herlina ${ }^{1 *}$, Triana Lindriati $^{1}$, N. Nurhayati ${ }^{1}$, S. Sulistiyani ${ }^{2}$, Manik Nur Hidayati ${ }^{2}$, Elok Sri Utami ${ }^{3}$, Siswoyo Soekarno ${ }^{1}$}

\author{
${ }^{1}$ Fakultas Teknologi Pertanian, Universitas Jember, \\ ${ }^{2}$ Fakultas Kesehatan Masyarakat, Universitas Jember, \\ ${ }^{3}$ Fakultas Ekonomi dan Bisnis, Universitas Jember, \\ Jl. Kalimantan 37, Kampus Tegal Boto Jember 68121 \\ *Penulis Korespondensi: Herlina, Email: lina.ftp@unej.ac.id
}

Tanggal submisi: 28 Maret 2019; Tanggal revisi: 8 Mei 2020, 24 Juli 2020;

Tanggal penerimaan: 3 September 2020

\begin{abstract}
ABSTRAK
Penelitian ini bertujuan untuk mengetahui pengaruh persentase subtitusi tepung koro pedang pada pembuatan tiwul instan protein tinggi terhadap karakteristik fisik, kimia dan organoleptik tiwul instan dan menentukan persentase subtitusi tepung koro pedang yang tepat sehingga dihasilkan tiwul instan yang disukai. Penelitian ini dilakukan dengan Rancangan Acak Lengkap (RAL) faktor tunggal, yaitu persentase subtitusi tepung koro pedang pada pembuatan tiwul instan dan setiap perlakuan dalam penelitian diulang 3 (tiga) kali. Data pengamatan yang didapatkan dianalisis menggunakan uji keragaman (ANOVA) taraf kepercayaan $95 \%(a \leq 0,05)$ dan apabila ada perbedaan yang nyata antar perlakuan $(a \leq 0,05)$ dilanjutkan dengan uji beda Duncan. Data uji organoleptik dianalisis menggunakan uji chi-square $(a \leq 0,05)$. Hasil penelitian ini menunjukkan, bahwa peningkatan persentase subtitusi tepung koro pedang menyebabkan peningkatan daya rehidrasi, daya kembang dan kadar protein tiwul instan protein tinggi, namun menyebabkan penurunan terhadap densitas kamba, kecerahan warna dan kadar air tiwul instan protein tinggi yang dihasilkan. Uji organoleptik kesukaan panelis didapatkan persentase tertinggi pada perlakuan P3 (persentase subtitusi tepung koro pedang 30\% ) dengan atribut memiliki daya rehidrasi 347\%, densitas kamba 0,51 g/mL, daya kembang 35,14\%, kecerahan warna 69,87, kadar air 6,05\%, dan kadar protein $8,15 \%$, serta persentase kesukaan warna, aroma, rasa, tekstur, dan kekenyalan berturut turut $56,40,62,68$, dan $64 \%$.
\end{abstract}

Kata kunci: Tiwul instan protein tinggi; tepung koro pedang; organoleptik; fisik; subtitusi 


\begin{abstract}
This study aimed to determine the effect of percentage jack bean flour on the physical, chemical and organoleptic of protein instant tiwul and determine the appropriate percentage of jack bean flour substitution to produce highprotein instant tiwul. This research used completely randomized design (CRD) with a single treatment, namely the percentage of jack bean flour substitution. Each treatment done in 3 (three) repetitions. The data obtained were analyzed using analysis of variance (ANOVA) test, and if there were significant differences between treatments ( $a \leq 0.05$ ), the duncan new multiple range test (DNMRT) was then carried out. Mean while, the organoleptic data were tested using the chi-square test $(a \leq 0.05)$. The results obtained from this study showed an increased percentage of jack bean flour substitution caused an increase rehydration power, swelling power and protein content of instant tiwul, but caused a decrease in bulk density, color lightness and water content of high-protein instant tiwul. In terms of organoleptic test of panelists' preference, the highest percentage was obtained in treatment P3 ( the percentage of jack bean flour substitution was 30\%) with attributes of $347 \%$ rehydration power, $0.51 \mathrm{~g} / \mathrm{mL}$ bulk density, $35.14 \%$ swelling power, 69.87 color lightness, $6.05 \%$ water content, and $8.15 \%$ protein content. The percentages of preference of color, flavour, taste, texture, and elasticity were 56, 40, 62, 68 , and $64 \%$, respectively.
\end{abstract}

Keywords: Organoleptic properties; substitution; physical characteristics; jack bean flour; high-protein instant tiwul

\section{PENDAHULUAN}

Ubi kayu atau singkong (Monihot uttilisima L.) tergolong jenis umbi dari suku euphorbiaceae, merupakan salah satu umbi lokal kaya karbohidrat yang berpotensi dikembangkan menjadi aneka produk makanan olahan. Di Indonesia, singkong merupakan sumber pangan pokok setelah padi dan jagung (Soetanto, 2008). Selama lima tahun terakhir produksi singkong mengalami peningkatan sebesar 3,84\% lebih besar dari tahun sebelumnya. Tahun 2011-2015 rata-rata luas panen singkong di tiga provinsi sentra tanaman singkong, 30,11\%, Jawa Timur sebesar 16,04\%, dan Jawa Tengah sebesar 15,17\% (Kementerian Pertanian, 2015).

Tanaman singkong tumbuh dengan baik di daerah tropika dan sub tropika, termasuk di Indonesia. Produksi singkong yang cukup tinggi, belum diimbangi dengan cara penanganan pasca panen yang tepat. Umbi singkong setelah dipanen bersifat perishable/mudah mengalami kerusakan, setelah di panen umbi singkong bertahan sekitar 4-5 hari, setelah itu akan mengalami kerusakan yang ditandai dengan warna umbi berubah menjadi hitam atau membiru. Oleh sebab itu diperlukan adanya diversifikasi produk olahan singkong untuk meningkatkan daya simpan singkong. Di Indonesia produk olahan singkong sangat beragam, dan dibeberapa daerah seperti provinsi Jawa Tengah dan Jawa Timur umbi singkong sudah diolah menjadi aneka produk makanan olahan seperti tiwul, gaplek, gatot, keripik, kerupuk, cookies, biskuit, tape, dan roti.

Tiwul adalah makanan tradisional berbahan baku dari tepung singkong ditambah gula, yang dilanjutkan dengan proses pengukusan. Produk tiwul diperlukan pengembngan lebih lanjut karena tiwul merupakan produk makanan olahan yang kaya karbohidrat tapi rendah komponen gizi yang lain, terutama protein. Kandungan protein tiwul instan tanpa penambahan komponen lain sekitar 1,65\% (Suhardi \& Suhardjo, 2006). Mensosialisasikan produk tiwul sebagai makanan pokok alternatif dapat mengatasi ketergantungan masyarakat akan bahan pangan tertentu seperti beras dan terigu, hal ini juga dapat menopang ketahanan pangan di Indonesia. Akan tetapi, saat ini tiwul semakin sulit dijumpai di masyarakat karena proses pembuatan tiwul diperlukan tahapan-tahapan khusus dan memakan waktu lama.

Masyarakat modern, saat ini memerlukan makanan siap saji, yang mempunyai nilai gizi seimbang, sehingga diperlukan pengembangan produk tiwul yang siap saji dengan kandungan gizi cukup, salah satu alternatif adalah produksi tiwul instan protein tinggi dengan penambahan tepung koro pedang (Canavalia ensiformis L.) sebagai sumber protein nabati. Selama ini koro pedang pemanfaatannya belum optimal, meskipun kandungan gizi koro pedang relative sama atau bahkan lebih besar dari kedelai, koro pedang memiliki kandungan protein mencapai 34-37\%, sementara kedelai sebesar 35,5\% (BPS, 2016). Kandungan protein pada koro pedang memiliki potensi untuk dimanfaatkan sebagai sumber makanan berprotein tinggi. Langkah yang baik untuk memadukan antara diversifikasi pangan dengan memberikan nilai tambah bagi produk pangan tradisional berbahan baku kearifan lokal adalah produksi tiwul instan protein tinggi bersubtitusi tepung koro pedang sebagai sumber protein. Sampai saat ini teknologi untuk memproduksi tiwul instan proein tinggi dan informasi sifat fisik, kimia dan organoleptik belum diinformasikan, sehingga diperlukan 
pengembangan produk tiwul instan dengan penambahan tepung koro pedang.

\section{METODE PENELITIAN}

\section{Bahan dan Alat}

Singkong sebagai bahan baku dalam penelitian ini didapatkan dari dusun Gludug, desa Pakis, kecamatan Panti, Kabupaten Jember dan Koro Pedang diperoleh dari Desa Cerme, Kecamatan Cerme, kabupaten Bondowoso, provinsi Jawa Timur, gula kristal putih merk gulaku, garam, air, kalium dikromat, etanol 97\%, kertas saring (Whatman 42), dan aquades.

Alat yang digunakan dalam penelitian ini adalah oven (Blower Excellent 53L UFE400), eksikator (Lokal $21 \mathrm{~cm}$ ), vortex (IKA), tabung reaksi (Pyrex $20 \mathrm{ml}$ ), spektrofotometer Genesys 10S UV-VIS, ayakan 80 mesh (Sieve), kompor (Rinnai RI-522E), colour reader Konica Minolta CR-10 Japan, beaker glass (Duran), gelas ukur (Shagufta), pisau (Stainless Lokal), dandang (Aluminium Lokal), penjepit, grinder, sendok, neraca analitik Ohaus BSA 2245, timbangan (Sigma Type SM 6000), blender (Phillips), dan vortex Max Mix 1 Type 16700.

Penelitian dilaksanakan pada beberapa laboratorium di lingkungan Universitas Jember dan Politeknik Negeri Jember, yaitu: Universitas Jember (Laboratorium Rekayasa Produk Hasil Pertanian, Laboratorium Kimia dan Biokimia, Laboratorium Manajemen Industri Pertanian, Laboratorium C-DAS, dan Laboratorium Mutu Terpadu), dan Politeknik Negeri Jember (Laboratorium BIOSAIN).

\section{Rancangan Percobaan}

Rancangan percobaan dalam penelitian ini digunakan rancangan acak lengkap dengan factor tunggal, adalah persentase subtitusi Tepung koro pedang pada pembuatan tiwul instan protein tinggi, setiap perlakuan dilakukan ulangan sebanyak 3 (tiga). Perlakuan persentase tepung singkong dan tepung koro pedang dan penelitian ini, secara rinci dapat dilihat pada Tabel 1.

Data yang diperoleh dilakukan pengujian sifat fisik, kimia, dan organoleptik. Data yang diperoleh dari pengujian fisik dan kimia dianalisis menggunakan analisis keragaman (ANOVA) dan jika antar perlakuan diperoleh perbedaan yang nyata (significan) dilanjutkan dengan uji beda DNMRT. Sedangkan data organoleptik dianalisis dengan chi-square.

\section{Teknologi Pembuatan Tepung Singkong}

Pembuatan tepung singkong diawali dengan singkong dikupas untuk dipisahkan antara kulit dan daging umbi, setelah dikupas singkong direndam
Tabel 1. Persentase tepung singkong dan koro pedang pada pembuatan tiwul instan

\begin{tabular}{ccc}
\hline Perlakuan & $\begin{array}{c}\text { Tepung singkong } \\
(\%)\end{array}$ & $\begin{array}{c}\text { Tepung koro pedang } \\
(\%)\end{array}$ \\
\hline P1 & 90 & 10 \\
P2 & 80 & 20 \\
P3 & 70 & 30 \\
P4 & 60 & 40 \\
P4 & 50 & 50 \\
\hline
\end{tabular}

dalah air untuk menghindari pencoklatan enzimatis, secepatnya singkong di diiris dengan ketebalan $\pm 1 \mathrm{~mm}$ menjadi chip. Chip basah di tiriskan dan di keringkan selama \pm 6 jam dengan sinar matahari, setelah agak kering dilakukan pengeringan dengan oven modifikasi yang dilengkapi dengan blower menggunakan suhu \pm $60-65^{\circ} \mathrm{C}$, selama \pm 12 jam. Chip singkong yang cukup kering digiling dan di ayak dengan ayakan 60 mess (Soetanto, 2008).

\section{Teknologi Pembuatan Tepung Koro Pedang}

Pembuatan tepung koro pedang diawali dengan koro pedang dimaserasi selama \pm 2 hari (48 jam) setiap 12 jam dilakukan penggantian air, kemudian dilanjutkan dengan pencucian dan perebusan \pm 1 jam untuk menetrasisir kandungan $\mathrm{HCN}$ yang terdapat di dalam koro pedang, biji koro pedang dikupas untuk dipisahkan antara kulit dan daging koro, setelah dikupas daging koro pedang di tiriskan dan di keringkan selama \pm 6 jam dengan sinar matahari, kemudian dilanjutkan dengan pengeringan oven modifikasi yang dilengkapi dengan blower pada suhu $\pm 60-65{ }^{\circ} \mathrm{C}$, selama 12 jam. Biji koro pedang yang sudah kering digiling menggunakan blender dan di ayak dengan ayakan 60 mesh (Ekanayake dkk., 2007).

\section{Pembuatan Tiwul Instan Protein Tinggi Bersubtitusi Tepung Koro Pedang}

Bahan utama pembuatan tiwul instan protein tinggi yaitu tepung singkong dilakukan proses pencampuran dengan tepung koro pedang dengan persentase yang sudah ditentukan (10; 20; 30; 40 dan 50\%) kemudian ditambah gula, garam dan air. Setelah seluruh adonan tercampur dilakukan pengukusan selama 20 menit agar adonan menjadi matang. Kemudian, adonan dilakukan pendinginan pada suhu ruang selama 12 jam dan dilakukan proses ekstrusi atau dibuat butiran-butiran halus. Langkah terakhir, dilakukan proses pengeringan pada suhu $55^{\circ} \mathrm{C}$ selama 2 jam (Rukmini HS. \& Naufalin R., 2016) 


\section{Parameter Pengamatan}

Parameter pengamatan meliputi pengamatan fisik, kimia dan organoleptik pengamatan fisikmeliputi kecerahan warna (colour reader), daya kembang (modifikasi), densitas kamba (modifikasi) dan daya rehidrasi (modifikasi) (Audu dan Aremu, 2011). Pengamatan secara kimia, yaitu kadar air (AOAC, 2007) dan kadar protein (George W. \& Latimer JR., 2007). Uji Organoleptik meliputi kesukaan warna, aroma, rasa, tekstur dan kekenyalan menggunakan uji kesukaan secara hedonic scale scoring yang mana panesis semi terlatih sebanyak 25 orang, diminta untuk menentukan nilai kesukaan produk dengan memberi nilai produk kisaran nilainya sudah ditentukan (1-7) (Mabesa, 1986).

\section{HASIL DAN PEMBAHASAN}

\section{Karakteristik Sifat Fisik Tiwul Instan}

\section{Daya rehidrasi}

Rehidrasi merupakan suatu kemampuan bahan pangan berpati yang menunjukkan seberapa besar kemampuannya dalam menyerap air, Suarni (2004) menyatakan bahwa daya rehidrasi tepung adalah kemampuan tepung untuk menyerap air, biasanya dinyatakan dalam persen. Rehidrasi dapat diperoleh dari berat bahan dalam satu gram bahan kering yang sudah dilarutkan dalam air kemudian di sentrifusi dan dilakukan perhitungan supernatannya (Hui, 1992).

Nilai rata-rata daya rehidrasi tiwul instan protein tinggi pada berbagai variasi persentase konsentrasi tepung koro pedang dapat dilihat pada Gambar 1, yaitu berkisar 302,5-349,0\%. Hasil uji ANOVA ( $a \leq 0,05)$ menunjukkan bahwa adanya subtitusi tepung koro pedang dalam tiwul instan berpengaruh nyata terhadap

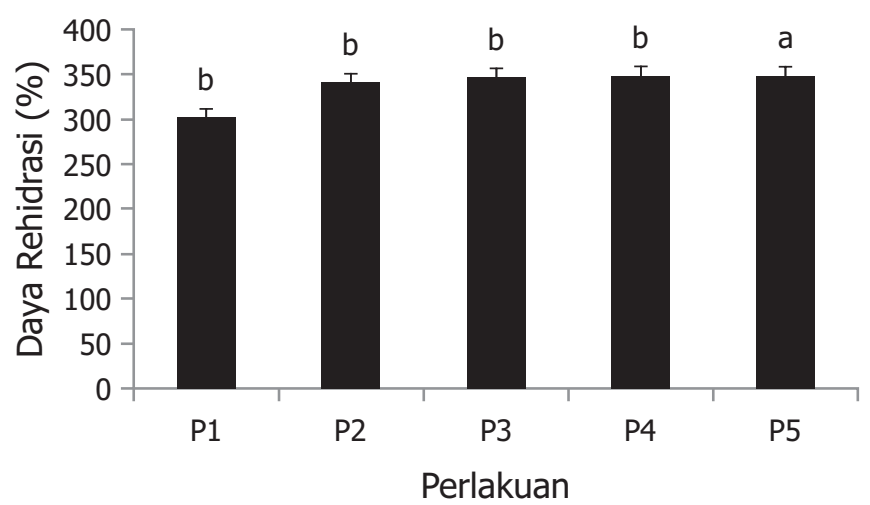

Gambar 1. Nilai rata-rata daya rehidrasi tiwul instan dengan varisasi persentase subtitusi tepung koro pedang daya rehidrasi tiwul instan sehingga dilanjutkan dengan Uji beda DNMRT.

Berdasarkan Gambar 1 dapat dilihat bahwa daya rehidrasi tiwul instan protein tinggi tertinggi diperoleh pada perlakuan P4 dan P5 (tepung koro pedang $=40$ dan $50 \%$ ) dengan nilai 349,0\% dan berbeda tidak nyata dengan perlakuan P3 (tepung koro pedang $=30 \%$ ) dan P2 (tepung koro pedang $=20 \%$ ). Nilai daya rehidrasi terendah diperoleh pada perlakuan subtitusi tepung koro pedang sebesar $10 \%$ (P1) dengan nilai $302,5 \%$, pada penelitian ini diperoleh bahwa semakin tinggi persentase subtitusi tepung koro pedang maka daya rehidrasi yang dihasilkan meningkat, kondisi ini dipengaruhi oleh kadar protein pada produk tiwul instan.

Kandungan protein pada produk sangat menentukan daya rehidrasinya, kenaikan kandungan protein pada produk akan meningkatkan daya rehidrasi produk. Kondisi tersebut disebabkan karena keberadaan protein pada tiwul instan akan meningkatkan jumlah gugus hidrofilik. Gugus hidrofilik pada protein memiliki sifat hidrofil, yaitu mampu menyerap air (Winarno, 2007). Menurut penelitian Agustia dkk. (2018) menyatakan bahwa subtitusi tepung koro pedang dan susu skim pada pembuatan tiwul instan akan meningkatkan daya rehidrasinya 2- 4 kali.

\section{Densitas Kamba}

Nilai densitas kamba (bulk density) adalah perbandingan antara berat bahan terhadap volumenya. Pada bahan pangan berupa tepung-tepungan nilai densitas kamba menunjukkan sifat fisiknya, selain itu nilai densitas kamba sangat diperlukan dalam desain alat pengemas produk. Bahan dengan nilai densitas kamba rendah menunjukkan bahwa, bahan tersebut memerlukan tempat yang lebih luas dibandingkan bahan yang memiliki nilai densitas kamba tinggi untuk berat yang sama, dengan demikian dapat disimpulkan

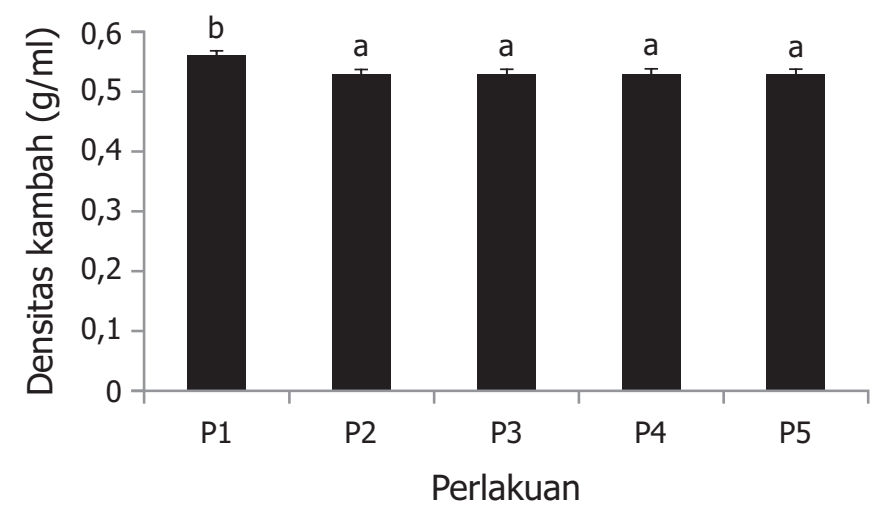

Gambar 2. Nilai rata-rata densitas kamba tiwul instan dengan variasi persentase subtitusi tepung koro pedang 
bahwa bahan yang memiliki densitas kamba kecil kurang efisien dalam segi pengemasan (Ade dkk., 2008).

Hasil penelitian menunjukkan bahwa nilai ratarata densitas kamba tiwul instan protein tinggi pada berbagai variasi persentase tepung koro pedang, yaitu berkisar antara 0,51-0,54 g/mL (Gambar 2). Hasil uji ANOVA $(a \leq 0,05)$ menunjukkan bahwa adanya subtitusi tepung koro pedang ke dalam tiwul instan berpengaruh nyata terhadap densitas kamba tiwul instan sehingga dilanjutkan uji DNMRT.

Berdasarkan Gambar 2 dapat diketahui bahwa densitas kamba tiwul instan protein tinggi dengan subtitusi tepung koro pedang, nilai tertinggi diperoleh pada perlakuan P1 (subtitusi tepung koro pedang $10 \%$ dengan nilai sebesar $0,54 \mathrm{~g} / \mathrm{mL}$, sedangkan perlakuan P2, P3, P4, dan P5 mempunyai nilai densitas kamba yang sama, yaitu $0,51 \%$. Nilai densitas kamba berbanding terbalik dengan jumlah subtitusi tepung koro pedang, semakin tinggi subtitusi tepung koro pedang maka nilai densitas kamba semakin kecil. Husain dkk. (2006) menyatakan bahwa densitas kamba sangat dipengaruhi oleh kadar air bahan, semakin tinggi kadar air maka nilai densitas kamba juga semakin meningkat, karena di dalam penentuan densitas kamba adalah berat bahan/ volume bahan (Muchtadi dan Sugiono, 1992).

Semakin tinggi kadar protein tiwul instan, maka densitas kamba yang dihasilkan akan semakin kecil dan ruang penyimpanan yang digunakan semakin besar. Kandungan protein pada bahan menyebabkan terbentuknya partikel yang semakin besar disebabkan oleh air yang terperangkap oleh granula protein, sehingga bahan semakin porous, dengan tingginya kandungan protein maka akan terbentuk granula yang besar, sehingga nilai densitas kamba semakin kecil (Gilang dkk., 2013). Nilai densitas kamba sangat dipengaruhi oleh karakteristik bahan, diantaranya adalah ukuran partikel (besar, kecil), bentuk partikel (pipih, bulat, beraturan, tidak beraturan, dan homogenitas), kadar air, ruang kosong (void) dan porositas (Heldman dan Singh 1981).

\section{Daya Kembang}

Daya kembang digunakan untuk mengukur kekuatan mengembang dari produk olahan tepung atau produk pati. Daya kembang dapat terjadi karena adanya ikatan non kovalen antar molekul pati, biasanya daya kembang terjadi pada daerah amorf granula pati. Saat proses pemanasan adonan tepung, maka ikatan hidrogen yang lemah antar molekul pati pada daerah amorf akan terputus sehingga terjadi penyerapan air oleh pati/proses hidrasi. Pengukuran daya kembang dapat dilakukan pada kisaran suhu terbentuknya pasta pati $\left(50-95^{\circ} \mathrm{C}\right)$ dengan interval $5^{\circ} \mathrm{C}$ (Swinkels \& Veendam, 1985).

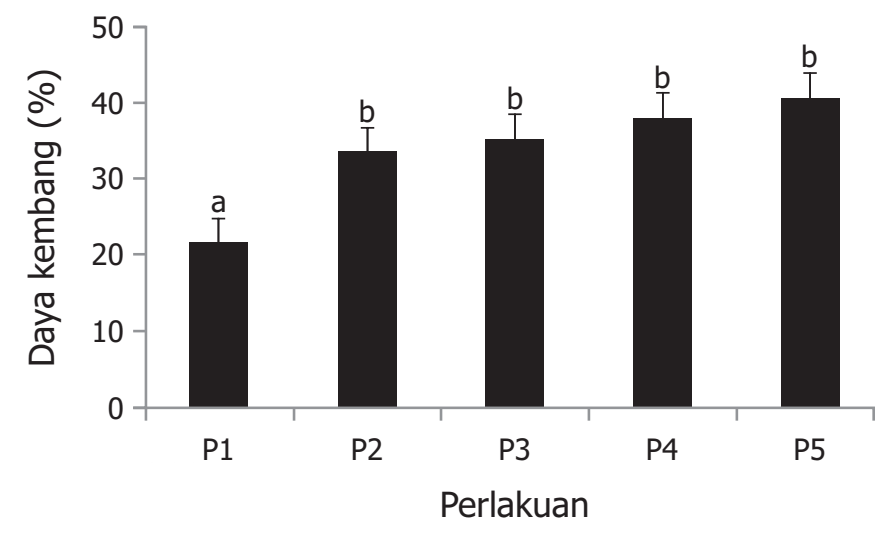

Gambar 3. Nilai rata-rata daya kembang tiwul instan dengan variasi persentase subtitusi tepung koro pedang

Hasil penelitian menunjukkan nilai rata-rata daya daya kembang tiwul instan protein tinggi pada berbagai variasi persentase konsentrasi tepung koro pedang dapat dilihat pada Gambar 3. Hasil uji ANOVA $(a \leq 0,05)$ menunjukkan bahwa adanya subtitusi tepung koro pedang ke dalam tiwul instan berpengaruh nyata terhadap daya kembang tiwul instan sehingga dilanjutkan dengan uji DNMRT.

Berdasarkan Gambar 3 dapat diketahui bahwa yang memiliki nilai daya kembang tertinggi yaitu pada perlakuan P5 (subtitusi tepung koro pedang $=50 \%$ ) sebesar $40,58 \%$ dan berbeda tidak nyata dengan perlakuan P2, P3, dan P4. Nilai daya kembang terendah diperoleh pada perlakuan P1 (subtitusi tepung koro pedang sebesar $10 \%$ ) yaitu $21,51 \%$. Hal tersebut dikarenakan semakin berkurangnya jumlah tepung singkong yang digunakan, dan semakin tinggi kandungan protein tiwul instan menyebabakan tiwul instan menjadi lebih tinggi daya kembangnya. Hal ini juga sesuai dengan daya rehidrasi, bahwa semakin tinggi daya rehidrasi maka semakin tinggi pula daya kembang dari tiwul instan. Penelitian Herastuti dan Firda (2015) menyatakan produk tiwul instan protein tinggi dengan subtitusi lembaga serealia dan konsentrat protein kedelai akan meningkatkan daya kembang produk.

Menurut Bemiller \& Whistler (1996) daya kembang pada produk berpati dipengaruhi oleh kandungan protein, perbandingan amilosa dan amilopektin, kandungan protein, panjang rantai atom c, dan berat molekul. Daya kembang amilosa lebih tinggi dibandingkan amilopektin, hal ini disebabkan amilosa lebih bersifat kering, kurang lekat dan cenderung higroskopis, sehingga menyerap air lebih banyak (Moorthy, 2004).

\section{Tingkat kecerahan warna (lightness)}

Kecerahan warna merupakan salah satu penentu kualitas produk pangan baik produk pangan olahan atau 


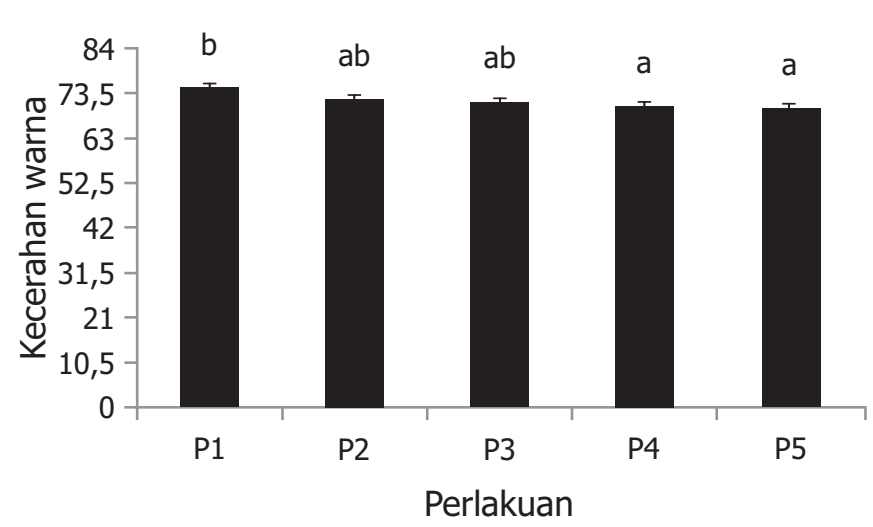

Gambar 4. Nilai rata-rata kecerahan warna tiwul instan dengan variasi persentase tepung koro pedang

segar. Perubahan warna pada produk pangan sering digunakan sebagai salah satu parameter perubahan kualitas atau perubahan sifat fisik maupun kimia produk tersebut. Pengamatan kecerahan warna dilakukan untuk menunjukkan tingkat kecerahan warna atau Lightness. Nilai kecerahan warna berkisar antara 0 sampai dengan 100, Nilai 100 menunjukkan tingkat kecerahan tinggi, sedangkan nilai 0 menunjukkan tingkat kecerahan rendah (gelap).

Hasil penelitian menunjukkan bahwa nilai ratarata kecerahan warna tiwul instan protein tinggi pada berbagai variasi persentase konsentrasi tepung koro pedang dapat dilihat pada Gambar 4, yaitu berkisar 68,58-73,32. Hasil uji ANOVA $(a \leq 0,05)$ menunjukkan bahwa adanya tepung koro pedang ke dalam tiwul instan berpengaruh nyata terhadap tingkat kecerahan warna tiwul instan sehingga dilanjutkan dengan uji DNMRT.

Berdasarkan Gambar 4 dapat diketahui bahwa subtitusi tepung koro pedang dapat mempengaruhi tingkat kecerahan warna tiwul instan, nilai tertinggi diperoleh pada perlakuan P1 (subtitusi tepung koro pedang $10 \%$ ) dengan nilai sebesar 73,32 dan nilai terendah diperoleh pada perlakuan P5 (subtitusi tepung koro pedang sebesar 50\%) dengan nilai 68,58 dan perlakuan $\mathrm{P} 5$ berbeda tidak nyata dengan perlakuan $\mathrm{P} 4$, P3, dan P2. Perubahan tersebut dikarenakan sifat fisik bahan utama yaitu tepung koro pedang yang memiliki kenampakan warna lebih gelap, sehingga mampu mempengaruhi produk akhir tiwul instan. Selain itu, warna tiwul yang dihasilkan juga dikarenakan perubahan selama proses pembuatan, proses pembuatan tiwul yang melibatkan gula pereduksi dan gugus amin yang dipicu oleh adanya pemanasan sehingga terbentuk senyawa melanoidin yang bertanggung jawab pada pembentukan warna lebih gelap (Kusnandar, 2010). Proses inilah yang disebut dengan reaksi maillard, hasil reaksi maillard dipengaruhi oleh konsentrasi

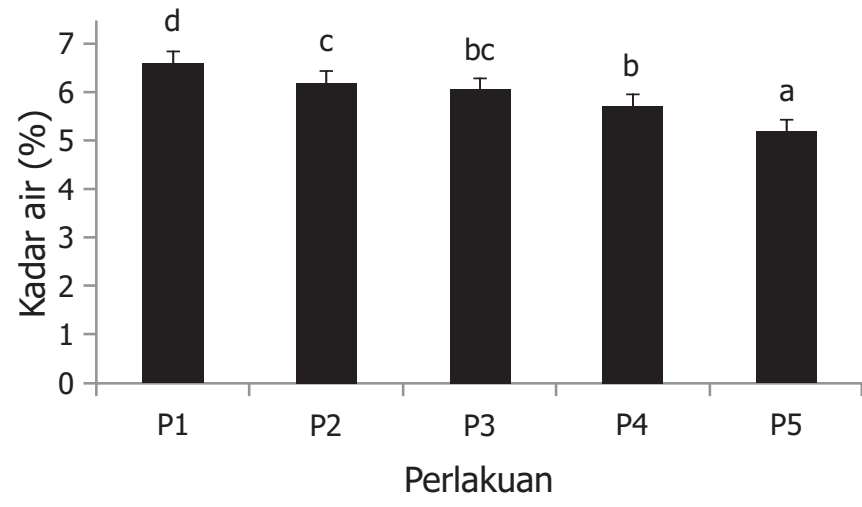

Gambar 5. Nilai rata-rata kadar air tiwul instan dengan variasi persentase subtitusi tepung koro pedang

gula, konsentrasi asam amino, tipe gula, suhu dan $\mathrm{pH}$ (Benyamin, 2012).

\section{Kerakteristik Sifat Kimia Tiwul Instan}

\section{Kadar air}

Kadar air menjadi faktor utama pada produk makanan instan, pada dasarnya kadar air yang melebihi batas normal akan menyebabkan makanan tersebut mudah mengalami kerusakan dan mudah ditumbuhi oleh mikroba. Penentuan kadar air merupakan salah satu karakteristik kimia bahan pangan untuk menunjukkan kandungan air yang ada pada bahan tersebut.

Hasil penelitian menunjukkan nilai rata-rata kadar air tiwul instan protein tinggi pada berbagai variasi persentase konsentrasi tepung koro pedang dapat dilihat pada Gambar 5, yaitu berkisar antara 5,21 $6,60 \%$. Hasil uji ANOVA $(a \leq 0,05)$ menunjukkan bahwa adanya subtitusi tepung koro pedang pada pembuatan tiwul instan berpengaruh nyata terhadap kadar air tiwul instan sehingga dilanjutkan dengan uji DNMRT.

Berdasarkan Gambar 5 menunjukkan bahwa semakin tinggi persentase subtitusi tepung koro pedang, akan menurunkan persen kadar air tiwul instan protein tinggi. Hal ini dikarenakan kadar air tepung koro pedang lebih rendah $(8,4 \%)$ apabila dibandingkan dengan tepung singkong (10\%) (Suhardi, 2006; Subagio dkk., 2006), sehingga semakin banyak subtitusi tepung koro pedang akan menurunkan nilai kadar air tiwul instan. Kandungan protein pada tiwul instan juga akan mempengaruhi persentase kadar air tiwul instan, kandungan protein yang lebih tinggi pada P5 (12,68\%) dibanding perlakuan P1 (4,05\%), maka P5 mempunyai kadar air lebih rendah dibanding P1, kondisi ini terjadi karena P5 mempunyai granula tiwul yang lebih porous, sehingga pada waktu proses pengeringan banyak air yang teruapkan (Winarno, 2007). 


\section{Kadar protein}

Zat gizi makro yang sangat penting bagi tubuh sebagai zat pembangun dan pengatur adalah protein. Protein sebagai penyusun bahan pangan sangat menentukan karakteristik bahan pangan tersebut, karena protein dapat berperan sebagai penstabil, emulsifier, pembentuk busa, dan pembentuk tekstur (Benyamin, 2012). Subtitusi tepung koro pedang ke dalam tiwul instan dapat meningkatkan kandungan gizi protein tiwul instan.

Nilai rata-rata kadar protein tiwul instan protein tinggi pada berbagai variasi persentase konsentrasi tepung koro pedang (Gambar 6), yaitu berkisar antara $4,05-12,68 \%$. Hasil uji ANOVA ( $a \leq 0,05)$ menunjukkan bahwa adanya subtitusi tepung koro pedang pada tiwul instan berpengaruh nyata terhadap kadar protein tiwul instan sehingga dilanjutkan dengan uji DNMRT.

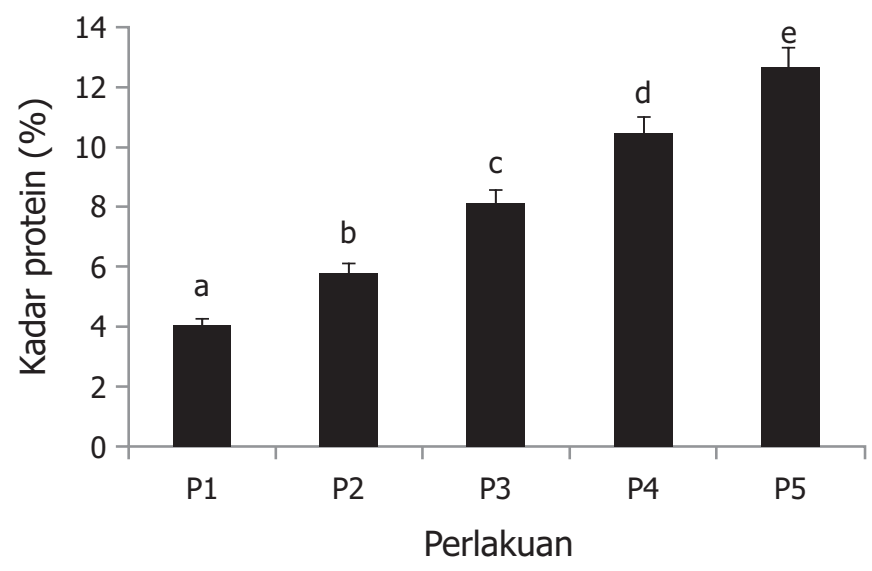

Gambar 6. Nilai rata-rata kadar protein tiwul instan dengan variasi persentase subtitusi tepung koro pedang

Gambar 6 menunjukkan bahwa subtitusi tepung koro pedang kedalam tiwul instan berbanding lurus terhadap kandungan total protein tiwul instan. Semakin banyak subtitusi tepung koro pedang, maka kandungan total protein juga akan semakin tinggi. Koro pedang mengandung $34-37 \%$ protein, sedangkan tepung singkong $1,4 \%$.

\section{Karakteristik Organoleptik Tiwul Instan}

\section{Tingkat kesukaan warna}

Kesukaan warna merupakan parameter utama penilaian panelis dalam memilih suatu produk pangan. Persepsi panelis terhadap atribut warna dapat mempengaruhi rasa produk yang dihasilkan. Hasil uji organoleptik dengan parameter agak suka - sangat suka menunjukkan bahwa persentase kesukaan panelis akan warna tiwul instan subtitusi tepung koro pedang berkisar antara $44-56 \%$, persentase kesukaan warna tiwul instan subtitusi tepung koro pedang dapat dilihat pada Tabel 2.

Tabel 2. Persentase kesukaan warna tiwul instan subtitusi tepung koro pedang

\begin{tabular}{ccccc}
\hline Perlakuan & $\begin{array}{c}\text { Agak suka } \\
(\%)\end{array}$ & $\begin{array}{c}\text { Suka } \\
(\%)\end{array}$ & $\begin{array}{c}\text { Sangat suka } \\
(\%)\end{array}$ & $\begin{array}{c}\text { Persentase } \\
(\%)\end{array}$ \\
\hline P1 & 16 & 28 & 4 & 48 \\
P2 & 28 & 24 & 0 & 52 \\
P3 & 28 & 20 & 8 & 56 \\
P4 & 28 & 16 & 4 & 48 \\
P5 & 28 & 16 & 0 & 44 \\
\hline
\end{tabular}

Hasil uji chi-square untuk penilaian kesukaan warna tiwul instan subtitusi tepung koro pedang menunjukkan bahwa variasi subtitusi tepung koro pedang berpengaruh nyata terhadap kesukaan warna panelis terhadap warna tiwul instan. Tabel 2 menunjukkan bahwa perlakuan P3 (subtirusi tepung koro pedang 30\%) yang sangat disukai panelis dengan persen kesukaan warna sebesar 56\%, sedangkan yang paling tidak disukai yaitu perlakuan P5 (subtitusi tepung koro pedang 50\%) dengan persen kesukaan warna sebesar $44 \%$.

Berdasarkan uji fisik kecerahan warna tiwul instan subtitusi tepung koro pedang diketahui bahwa perlakuan P3 memiliki nilai kecerahan warna sebesar 69,87 dan perlakuan P5 memiliki nilai kecerahan warna sebesar 68,58, sehingga warna tiwul instan P3 memiliki warna yang lebih terang dibandingkan dengan P5 yang cenderung lebih gelap. Faktor yang mempengaruhi warna pada proses pengolahan tiwul instan antara lain bahan baku yang digunakan, komposisi bahan baku (rasio karbohidrat dan protein) yang menyebabkan reaksi maillard (Winarno, 2007). Reaksi maillard terjadi dengan adanya gula pereduksi dan senyawa gugus amin yang dipicu oleh adanya pemanasan, sehingga terbentuk senyawa melanoidin yang berwarna gelap (Kusnandar, 2010). Peningkatan kecepatan terjadinya reaksi maillard sangat dipengaruhi oleh kadar air, suhu, dan pH (Oliveira dkk., 2016).

\section{Tingkat kesukaan aroma}

Aroma atau flavour produk pangan adalah dalah satu parameter penting dan perlu diperhatikan dalam pembuatan produk pangan. Hasil uji organoleptik dengan parameter agak suka - sangat suka menunjukkan bahwa persentase kesukaan panelis akan aroma tiwul 
instan yang disubtitusi tepung koro pedang berkisar antara $16-40 \%$, persentase kesukaan aroma tiwul instan subtitusi tepng koro pedang secara rinci dapat dilihat pada Tabel 3.

Tabel 3. Persentase kesukaan aroma tiwul instan disubtitusi tepung koro pedang

\begin{tabular}{ccccc}
\hline Perlakuan & $\begin{array}{c}\text { Agak suka } \\
(\%)\end{array}$ & $\begin{array}{c}\text { Suka } \\
(\%)\end{array}$ & $\begin{array}{c}\text { Sangat suka } \\
(\%)\end{array}$ & $\begin{array}{c}\text { Persentase } \\
(\%)\end{array}$ \\
\hline P1 & 16 & 16 & 0 & 32 \\
P2 & 12 & 12 & 0 & 24 \\
P3 & 24 & 16 & 0 & 40 \\
P4 & 8 & 16 & 0 & 24 \\
P5 & 0 & 16 & 0 & 16 \\
\hline
\end{tabular}

Hasil uji chi-square dapat diketahui bahwa persentase subtitusi tepung koro pedang berpengaruh nyata terhadap kesukaan panelis akan aroma tiwul instan yang dihasilkan. Tabel 3 menunjukkan bahwa nilai tertinggi tingkat kesukaan aroma terdapat pada perlakuan P3 (subtitusi tepung koro pedang 30\%) yaitu sebesar $40 \%$. Sedangkan nilai yang paling rendah pada perlakuan P5 (subtitusi tepung koro pedang 50\%) yaitu sebesar $16 \%$. Hal ini disebabkan pada perlakuan P5 aroma tiwul instan didominasi aroma tepung koro pedang, sehingga originalitas tiwul hilang. Aroma khas tiwul akan semakin hilang dengan meningkatnya jumlah subtitusi tepung koro pedang ke dalam tiwul instan yang disebabkan oleh reaksi maillard. Benyamin (2012) mengatakan bahwa terjadinya reaksi maillard pada produk pangan dapat mempengaruhi kualitasnya, sebab reaksi ini akan mempengaruhi aroma, rasa, dan warna.

\section{Tingkat kesukaan rasa}

Atribut rasa merupakan salah satu parameter penentu kualitas dan penerimaan produk tersebut terhadap konsumen. Rasa juga dapat menentukan peresepsi konsumen baik atau buruk terhadap produk pangan. Hasil uji organoleptik dengan parameter agak suka - sangat suka menunjukkan bahwa persentase kesukaan panelis akan rasa tiwul instan subtitusi tepung koro pedang berkisar antara $40-62 \%$ secara rinci dapat dilihat pada Tabel 4.

Hasil uji chi-square menunjukkan bahwa, subtitusi tepung koro pedang pada tiwul instan berpengaruh nyata terhadap kesukaan panelis akan rasa tiwul instan. Tabel 4 terlihat bahwa persentase nilai kesukaan tertinggi terdapat pada perlakuan P3 ( subtitusi tepung koro pedang $30 \%$ ) dengan nilai $62 \%$ dan persentase nilai kesukaan terendah terdapat pada perlakuan
Tabel 4. Persentase kesukaan rasa tiwul instan subtitusi tepung koro pedang

\begin{tabular}{ccccc}
\hline Perlakuan & $\begin{array}{c}\text { Agak suka } \\
(\%)\end{array}$ & $\begin{array}{c}\text { Suka } \\
(\%)\end{array}$ & $\begin{array}{c}\text { Sangat suka } \\
(\%)\end{array}$ & $\begin{array}{c}\text { Persentase } \\
(\%)\end{array}$ \\
\hline P1 & 40 & 8 & 0 & 48 \\
P2 & 40 & 20 & 0 & 60 \\
P3 & 24 & 28 & 10 & 62 \\
P4 & 32 & 20 & 8 & 60 \\
P5 & 28 & 8 & 4 & 40 \\
\hline
\end{tabular}

P5 (subtitusi tepung koro pedang 50\%) dengan nilai $40 \%$. Hal tersebut dikarenakan pada perlakuan P5 rasa tiwul instan didominasi rasa tepung koro pedang, sehingga originalitas tiwul hilang. Rasa khas tiwul akan semakin hilang dengan meningkatnya jumlah subtitusi tepung koro pedang kedalam tiwul instan yang disebabkan oleh reaksi maillard. Reaksi maillard dapat mempengaruhi rasa, aroma dan warna pada produk pangan (Benyamin, 2012). Menurut Pedreschi dkk. (2005), bahwa senyawa melanoidin yang terjadi pada reaksi maillard mengakibatkan terjadinya warna coklat pada produk pangan dan memberikan rasa pahit, serta rasa yang khas pada produk pangan. Terjadinya reaksi maillard tidak hanya menghasilkan rasa yang di kehendaki, tetapi kadang kala menghasilkan cita rasa yang tidak dikehendaki/menyimpang, sehingga dapat merusak cita rasa makanan.

\section{Tingkat kesukaan tekstur}

Tekstur merupakan salah satu atribut yang nampak dari segi fisik suatu produk pangan. Tekstur yang dimiliki setiap produk pangan relatif berbeda tergantung jenis produk dan bahan yang digunakan dalam pembuatan produk tersebut. Setiap orang memiliki tingkat kesukaan tekstur produk pangan yang berbeda. Hasil uji organoleptik dengan parameter agak suka - sangat suka menunjukkan bahwa persentase kesukaan panelis terhadap tekstur tiwul instan yang disubtitusi dengan tepung koro pedang berkisar antara $44-68 \%$, dapat dilihat pada Tabel 5.

Hasil uji chi-square persentase subtitusi tepung koro pedang pada pembuatan tiwul instan berpengaruh nyata terhadap tekstur tiwul instan. Tabel 5 menunjukkan bahwa nilai kesukaan panelis akan tekstur tiwul instan tertinggi terdapat pada perlakuan P3 (subtitusi tepung koro pedang sebesar 30\%) dengan nilai persentase sebesar $68 \%$ dan nilai persentase kesukaan terendah pada perlakuan P1 (subtitusi tepung koro pedang sebesar $10 \%$ ) dengan nilai $44 \%$. Hal ini disebabkan adanya keseimbangan antara pati dan protein pada bahan yang seimbang mengakibatkan tekstur tiwul 
Tabel 5. Persentase kesukaan tekstur tiwul instan subtitusi tepung koro pedang

\begin{tabular}{ccccc}
\hline Perlakuan & $\begin{array}{c}\text { Agak suka } \\
(\%)\end{array}$ & $\begin{array}{c}\text { Suka } \\
(\%)\end{array}$ & $\begin{array}{c}\text { Sangat suka } \\
(\%)\end{array}$ & Persentase \\
\hline P1 & 28 & 16 & 0 & 44 \\
P2 & 32 & 24 & 0 & 56 \\
P3 & 36 & 12 & 20 & 68 \\
P4 & 12 & 36 & 4 & 52 \\
P5 & 12 & 28 & 8 & 48 \\
\hline
\end{tabular}

instan menjadi lebih baik, hal ini disebabkan pati hanya mampu mengikat air hingga volume hidrasi maksimum (Swinkels \& Veendam, 1985). Berdasarkan penelitian Agustia dkk. (2018), menyatakan bahwa produk tiwul instan dengan subtitusi koro pedang pra germinasi mempunyai tekstur sedang.

\section{Tingkat kesukaan kekenyalan}

Kekenyalan produk makanan adalah merupakan parameter penting untuk menentukan kualitas pangan. Hasil uji organoleptik dengan parameter agak suka sangat suka menunjukkan bahwa persentase kesukaan panelis akan kekenyalan tiwul instan yang disubtitusi tepung koro pedang berkisar antara $24-64 \%$, secara rinci persentase kesukaan panelis akan kekenyalan tiwul instan (Tabel 6).

Tabel 6. Persentase kesukaan kekenyalan tiwul instan subtitusi tepung koro pedang

\begin{tabular}{ccccc}
\hline Perlakuan & $\begin{array}{c}\text { Agak suka } \\
(\%)\end{array}$ & $\begin{array}{c}\text { Suka } \\
(\%)\end{array}$ & $\begin{array}{c}\text { sangat suka } \\
(\%)\end{array}$ & $\begin{array}{c}\text { Persentase } \\
(\%)\end{array}$ \\
\hline P1 & 28 & 24 & 0 & 52 \\
P2 & 28 & 32 & 0 & 60 \\
P3 & 36 & 24 & 4 & 64 \\
P4 & 20 & 24 & 0 & 44 \\
P5 & 8 & 16 & 0 & 24 \\
\hline
\end{tabular}

Hasil uji chi-square menunjukkan bawwa subtitusi tepung koro pedang pada tiwul instan berpengaruh nyata terhadap tingkat kekenyalan tiwul instan. Tabel 6 menunjukkan hasil pengujian organoleptik dengan parameter kesukaan kekenyalan, mempunyai nilai persentase kesukaan paling tinggi pada perlakuan P3 (subtitusi tepung koro pedang 30\%) dengan nilai 64\% dan nilai kesukaan paling rendah pada perlakuan P5 (subtitusi tepung koro pedang 50\%) dengan nilai $24 \%$. Hal tersebut menunjukkan bahwa panelis menyukai tiwul instan dengan kekenyalan sedang. Tingkat kekenyalan tiwul instan dipengaruhi oleh kandungan amilopektin pada bahan. Kandungan amilopektin tepung singkong sebesar 72,62\% (Murtiningrum dkk., 2016). Kekenyalan pada tiwul instan juga disebabkan oleh kandungan pati pada bahan, pati pada bahan (tiwul instan) mengalami hidrasi hingga mencapai maksimum, yang diikuti dengan proses pengembangan pada bahan (Swinkels \& Veendam, 1985).

\section{KESIMPULAN}

Kesimpulan dalam penelitian ini adalah: 1) peningkatan persentase subtitusi tepung koro pedang menyebabkan peningkatan daya rehidrasi, daya kembang dan kadar protein tiwul instan, namun menyebabkan penurunan terhadap densitas kamba, kecerahan warna dan kadar air tiwul instan yang dihasilkan; 2) Berdasarkan uji kesukaan panelis didapatkan persentase tertinggi pada perlakuan P3 (subtitusi tepung koro pedang sebesar 30\%) dengan atribut memiliki daya rehidrasi $347 \%$, densitas kamba $0,51 \mathrm{~g} / \mathrm{mL}$, daya kembang $35,14 \%$, kecerahan warna 69,87 , kadar air 6,05\%, dan kadar protein 8,15\%, serta persentase kesukaan warna, aroma, rasa, tekstur, dan kekenyalan berturut turut $56,40,62,68$, dan 64\%.

\section{UCAPAN TERIMA KASIH}

Terima kasih penulis ucapkan kepada anggota Kelompok Riset (KERIS) Ketahanan Pangan Universitas Jember, atas kerjasamanya dalam pelaksanaan penelitian ini dan kepada Lembaga Penelitian dan pengabdian Kepada Masyarakat (LP2M) Universitas Jember yang telah membiayai penelitian ini melalui hibah penelitian KERIS tahun anggaran 2018.

\section{KONFLIK KEPENTINGAN}

Penulis menyatakan bahwa tidak ada kepentingan dari berbagai pihak pada penelitian ini.

\section{DAFTAR PUSTAKA}

Ade-Omowaye, B.I.O., Akinwande, B.A., Bolarinwa, I.F., \& Adebiyi, A.O. (2008). Evaluation of tigernut (Cypperus esculentus)-wheat composite flour and bread. Afric $J$ Food Sci. 2:87-91. DOI: 10.5897/AJFS

Agustia, F.C., Subardjo, Y.P. \& Sari, H.P. (2017). Pengembangan biskuit mocaf-garut dengan substitusi hati sebagai alternatif biskuit tinggi zat besi untuk balita. Journal of Nutrition and Food, 12(2):129-138. DOI: 10.25182/ jgp.2017.12.2.129-138. 
AOAC. (2007). Official methods of analysis, (12 ${ }^{\text {th }}$ ed). Association of official analytical chemists. Washington, D.C . DOI: 10.3923/pjn.2011.1069.1075.

Audu, S.S., \& Aremu, M.O. (2011). Effect of processing on chemial composition of red kidney bean (Phaseolus vulgaris L.) flour. Pakistan Journal Nutrition, 10(11): 1069-1075. doi:10.3923/pjn.208.1069.1075. https:// dx.doi.org/10.3923/pjn.2011.1069.1075

Benyamin, K.S. (2012). Food biochemistry and food processing, $2^{\text {nd }}(\mathrm{ed})$. John Wiley \& Sons, Inc. New York. DOI: $10.1002 / 9781118035$

BeMiller, J.N. \& Whistler, R.L. (1996). Carbohydrates in food chemistry. O. R. Fennema (ed.). New York: Marcel Dekker Inc.

Badan Pusat Statistik. (2016). Produksi dan luas tanaman singkong di indonesia. Jakarta: Badan Pusat Statistik Indonesia.

Ekanayake S., Skog, K. \& Asp, N.G. (2007) Canavanine content in sword beans (Canavalia gladiata), analysis and effect of processing. Journal Food and Chemical Toxicology Vol. 45: 797-803. doi: 10.1016/j.fct.2006.10.030.

Friska, C.A., Herastuti, S.R., \& Risda, N. (2018). Formulasi tiwul instan tinggi protein dari tepung ubi kayu yang disubtitusi tepung koro pedang dan susu skim. Jurnal Aplikasi Teknologi Pangan 7(1). https://doi. org/10.17728/jatp.2131

Gilang, R., Affandi, D. R., \& Ishartani, D. (2013). Karakteristik fisik dan kimia tepung koro pedang (canavalis ensiformis) dengan variasi perlakuan pendahuluan. Jurnal Teknosains Pangan 2(3). www.ilmupangan. fp.uns.ac.id.

Heldman, D. R. \& Singh, P. R. (1981). Food Proses Enginering. $2^{\text {nd }}$ ed. The AVI Publ. Comp., Inc. Westrop. CT, USA

Herastuti, S.R. \& Naufalin, R. (2012). Formulasi tiwul instan tinggi protein untuk mempercepat diversifikasi pangan. Laporan Penelitian Strategis Nasional, DP2M DIKTI.

Hui, Y.H. (1992). Encyclopedia of Food Science dan Technology. John Wiley and Sons, Inc., New York.

Oliveira, F. C. D., Coimbra J. S. D. R., de Oliveira E. B., Zuñiga A. D. G., \& Rojas E. E. G. (2014). Food ProteinPolysaccharide Conjugates obtained via the Maillard
Reaction: A Review. Crit Rev Food Sci Nutr. 13:37-41. doi: 10.1080/10408398.2012.755669.

Kementerian Pertanian. (2015). Outlook Ubi Kayu. Pusat Data dan Sistem Informasi Pertanian Kementerian Pertanian. Jakarta.

Kusnandar F. (2010). Teknologi Modifikasi Pati dan Aplikasinya di Industri Pangan. http://itp.fateta.ipb.ac.id/. [Akses tanggal 8 Februari 2018].

Mabesa, I.B. (1986). Sensory Evaluation of Foods principles and Methods. College of Agriculture, laguna.

Moorthy, S.N. (2004). Tropical sources of starch. Florida: CRC Press, Baco Raton.

Muchtadi \& Sugiono. (1992). Densitas Kamba. Jakarta; Gramedia Pustaka

Murtiningrum. (2012). Pengaruh Preparasi Ubi Jalar (Ipomea batatas) sebagai Bahan Pengental terhadap Komposisi Kimia dan Sifat Organoleptik Saus Buah Merah (Pandanus conoideus L). Jurnal Agrointek. Vol 6, no.1.

Rukmini, H.S., \& Naufalin, R. (2015). Formulasi Tiwul Instan Tinggi Protein Melalui Penambahan Lembaga Serealia dan Konsentrat Protein Kedelai. Jurnal Teknologi Industri Pertanian. 25(3): 190-197. https://journal. ipb.ac.id/index.php/jurnaltin/article/view/11784

Suarni. (2004). Pemanfaatan tepung sorgum untuk produk olahan. J Litbang Pert. 23(4):145-151. https://pangan. litbang.pertanian.go.id/files/08-Suarni.pdf

Subagyo, A. (2006). Pengembangan Tepung Ubi Kayu sebagai Bahan Industri Pangan. Seminar Rusnas Diversifikasi Pangan Pokok Industrialisasi Diversifikasi Pangan Berbasis Potensi Pangan Lokal. Kementrian Ristek dan Seafast Center. IPB. Serpong.

Suhardi \& Suhardjo (2006). Teknologi produksi tiwul instan dari tepung ubi kayu komposit. Info Teknologi Pertanian No.27Tahun 2006. Balai Pengkajian Teknologi Pertanian. Jawa Timur.

Swinkels \& Veendams. (1985). Composition and Properties of Comercial Native Starches. Starch, 37: 1-5.

Winarno F.G. (2007). Kimia Pangan dan Gizi. Jakarta: Gramedia Pustaka Utama. 